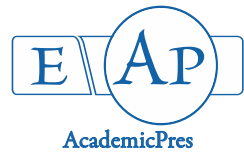

\title{
Agronomic Performance of Sweet Potato (Ipomoea batatas (L.) Lam) Fertilized with Poultry Manure Enriched with Oil Palm Refuse Bunch Ash in a Low Fertile Soil
}

\section{Kolawole LAW-OGBOMO*, Sunday OGEDEGBE, Sylvester EWANSIHA}

\author{
University of Benin, Faculty of Agriculture, Department of Crop Science, PMB 1154, Benin City, \\ Nigeria; edomwonyi.law-ogbomo@uniben.edu('correspondingauthor); sunday.ogedegbe@uniben.edu; sylvester.ewansiha@uniben.edu
}

\begin{abstract}
A field experiment was conducted to investigate the efficiency of poultry manure enriched with oil palm refuse bunch ash (OPRBA) on the growth and yield of sweet potato in a low fertile soil. The experiment was laid out in a randomized complete block design with three replications. The treatments involved five rates $\left(0,2,4,6\right.$ and $\left.8 \mathrm{t} \mathrm{ha}^{-1}\right)$ of oil palm refuse bunch ash (OPRBA) in the first year of the experiment. In the second year, the treatments were $0,4,6,8$ and $10 \mathrm{t} \mathrm{ha}^{-1} \mathrm{of} \mathrm{OPRBA}^{\text {. All }}$ plots were treated with a basal application of $15 \mathrm{t} \mathrm{ha}^{-1}$ of poultry manure. Data were collected on vine length $(\mathrm{cm})$, number of branches, number of nodes, number of leaves, leaf area index (LAI) and total dry weight $\left(\mathrm{g} \mathrm{m}^{-2}\right)$ at 8 weeks after planting. Data on yield components were collected on tuber length $(\mathrm{cm})$, tuber girth $(\mathrm{cm})$, number of tubers, tuber size $(\mathrm{kg})$, tuber weight $(\mathrm{kg})$ and tuber yield $\left(\mathrm{t} \mathrm{ha}^{-1}\right)$. The results showed that vine length, number of branches, number of nodes, number of leaves and leaf area index and total dry weight increased significantly $(\mathrm{p}<0.05)$ while increasing the rate of OPRBA. The highest tuber yield $\left(50.22 \mathrm{t} \mathrm{ha}^{-1}\right)$ was recorded for plants treated with $6 \mathrm{t} \mathrm{ha}^{-1}$ of OPRBA in 2016. In 2017, plants treated with 6,8 and $10 \mathrm{t}$ $\mathrm{ha}^{-1}$ OPRBA had the highest tuber yield $\left(29.10,30.00\right.$ and $32.00 \mathrm{t} \mathrm{ha}^{-1}$, respectively). Tuber yield correlated significantly ( $\mathrm{p}<$ $0.05)$ and positively with total dry weight $(r=0.748)$, LAI $(r=0.938)$, number of branches $(r=0.679)$, number of leaves $(r=$ $0.879)$, number of nodes $(r=0.440)$, number of tubers $(r=0.561)$, tuber girth $(r=0.751)$, tuber length $(r=0.864)$, tuber size $(\mathrm{r}=0.952)$ and vine length $(\mathrm{r}=0.940)$. It is therefore suggested that poultry manure at the rate of $15 \mathrm{tha}^{-1}$ should be enriched with OPRBA at the rate of $6 \mathrm{tha}^{-1}$ for optimum production of sweet potato.
\end{abstract}

Keywords: growth; OPRBA; poultry manure; total dry weight; tuber yield

Farmers make use of inorganic fertilizers in order to increase yield. Continuous use of these agrochemicals has been found to increase yield for some years, but on the longrun, it leads to decreasing base saturation and soil physical degradation (Isherwood, 2008).

Nyakatawa et al. (2001) suggested that it is possible to increase yield of sweet potato crop on degraded soil by using organic resources such as plants and animal wastes for soil fertility improvement. However, some animal wastes, such as poultry manure, are low in potassium and phosphorus.

Oil palm refuse bunch ash (OPRBA) is rich in potassium and phosphorus, but low in nitrogen. Using poultry manure alone without supplementing it with other nutrient sources for the adequate provision of potassium and phosphorus will not make the crop to reach its full potential in terms of yield. Therefore, it is important to ascertain how poultry manure affects the growth and tuber yield of sweet potato when enriched with OPRBA. This will provide a well-balanced nutrient base for the crop and reduce farmers' dependence on the use of inorganic fertilizer.

Received: 24 Dec 2018. Received in revised form: 03 Sep 2019. Accepted: 13 Sep 2019. Published online: 30 Sep 2019. 
Hence, the present study was conducted to evaluate the growth and yield responses of sweet potato to poultry manure when enriched with different rates of OPRBA in a low fertile soil.

\section{Materials and Methods}

\section{Experimentalsite}

The study was conducted started in the late rainy season of 2016 and lasted until 2017, at the Experimental Farm of the Faculty of Agriculture, University of Benin, Benin City, Nigeria. The site is located within Latitude $6^{\circ} 44^{\prime} \mathrm{N}$ and Longitude $5^{\circ} 40^{\prime} \mathrm{E}$ in the humid rainforest at an elevation of $162 \mathrm{~m}$. The area is characterized by a bimodal rainfall pattern with a long rainy season which commences in March and the short rainy season that extends from September to late October after a short dry spell in August. The dominant soil order in the studied area is ultisols developed from coastal plain sand.

Prior to field experimentation, composite soil sample was obtained from the experimental site and was analysed for its physical and chemical properties using standard laboratory procedures as outlined by Mylavarapus and Kennelley (2002). The results of the soil analysis are given in Table 1. The dominant weed species at the site were Guinea grass (Panicum maximum) and Mimosa spp.

Poultry manure and oil palm refuse bunch ash (OPRBA)

The poultry manure was obtained from under the battery cage of the layers' unit of the University commercial farm and cured under shade for four weeks. Oil palm refuse bunches were obtained from a palm oil mill factory at "Edaiken" Market, Uselu and burned to obtained the ash. Cured poultry manure and oil palm refuse bunch ash (OPRBA) were analyzed for their chemical composition as given in Table 1.
Experimental design and treatments

The experiment was laid out in a randomized complete block design with three replications. The treatments involved five rates $\left(0,2,4,6\right.$ and $\left.8 \mathrm{t} \mathrm{ha}^{-1}\right)$ of OPRBA in 2016. In 2017, the treatments were $0,4,6,8$ and $10 \mathrm{tha}^{-1}$ of OPRBA. Each plot measured $2 \times 3 \mathrm{~m}$ with a spacing of 0.50 $\mathrm{m}$ between plots and $1.00 \mathrm{~m}$ between blocks.

\section{Cultural practices}

Sweet potato tubers were planted in a nursery bed on 19 August, 2016 and repeated on the same period in 2017. For both nursery and field, cured poultry manure was incorporated into the soil at a rate of $15 \mathrm{tha}^{-1}$ four weeks prior to planting and the soil was mulched with dry grasses.

At planting, vines of $40 \mathrm{~cm}$ length with four nodes were collected from the apical meristem and planted at a spacing of $1 \mathrm{~m}$ between ridges and $0.30 \mathrm{~m}$ within rows, during the early hours of the day, using a sharp knife. The vines were planted at an angle of $45^{\circ}$ and a planting depth of $5 \mathrm{~cm}$. The plots were irrigated immediately after planting. At planting, OPRBA was applied according to the treatment plan. Missing plots were supplied 8 days after planting. Weeding was done manually using hoes two weeks after planting and subsequently as was necessary. Harvesting was done at 18 weeks after planting when the leaves and vines have turned brown and dried up. Harvesting was done by removing the dried vines using cutlass and uprooting the tubers using spade and hoes.

\section{Data collection}

During the growing phase, data were taken on three plants randomly selected from the inner-row of each net plot for number of branches, vine length, number of nodes, number of leaves, leaf area index (LAI) and total dry weight at 8 weeks after planting. Sweet potato leaf area (LA) was estimated using Ogoke et al. (2003) formula as follows:

Table 1. The physical and chemical properties of the soil of the experimental site prior to cropping and the chemical composition of poultry manure and oil palm refuse ash

\begin{tabular}{|c|c|c|c|c|c|c|}
\hline \multirow{2}{*}{ Parameter } & \multicolumn{2}{|c|}{ Soil } & \multicolumn{2}{|c|}{ Poultry manure } & \multicolumn{2}{|c|}{ OPRBA } \\
\hline & 2016 & 2017 & 2016 & 2017 & 2016 & 2017 \\
\hline Sand $\left(\mathrm{g} \mathrm{kg}^{-1}\right)$ & 884.00 & 887.00 & $\mathrm{NA}$ & $\mathrm{NA}$ & NA & NA \\
\hline Silt $\left(\mathrm{g} \mathrm{kg}^{-1}\right)$ & 60.00 & 65.00 & NA & NA & NA & NA \\
\hline Clay $\left(\mathrm{g} \mathrm{kg}^{-1}\right)$ & 55.00 & 48.00 & NA & $\mathrm{NA}$ & NA & NA \\
\hline $\mathrm{pH}\left(\mathrm{H}_{2} \mathrm{O} 1: 1\right)$ & 5.40 & 5.60 & 7.70 & 6.76 & 8.50 & 8.40 \\
\hline Organic carbon $\left(\mathrm{g} \mathrm{kg}^{-1}\right)$ & 15.20 & 12.03 & 26.20 & 28.70 & 12.40 & 0.50 \\
\hline Total nitrogen $\left(\mathrm{g} \mathrm{kg}^{-1}\right)$ & 0.76 & 0.85 & 3.00 & 2.45 & 1.76 & 0.50 \\
\hline Available phosphorus $\left(\mathrm{g} \mathrm{kg}^{-1}\right)$ & 8.10 & 7.24 & 11.80 & 10.20 & 15.12 & 23.80 \\
\hline \multicolumn{7}{|l|}{ Exchangeable cation $\left(\mathrm{cmol} \mathrm{kg}^{-1}\right)$} \\
\hline Calcium & 0.80 & 0.81 & 2.03 & 1.29 & 43.10 & 13.82 \\
\hline Magnesium & 0.24 & 0.25 & 0.26 & 0.24 & 30.10 & $12 . .04$ \\
\hline Potassium & 0.23 & 0.22 & 0.18 & 0.17 & 13.40 & 33.45 \\
\hline Sodium & 0.14 & 0.14 & 0.23 & 0.16 & 3.68 & 3.88 \\
\hline \multicolumn{7}{|l|}{ Exchangeable acidity $\left(\mathrm{cmol} \mathrm{kg}^{-1}\right)$} \\
\hline Hydrogen & 0.30 & 1.25 & NA & NA & NA & NA \\
\hline Aluminum & 1.00 & 0.26 & NA & NA & NA & NA \\
\hline NA - Not applicable & & & & & & \\
\hline
\end{tabular}


410

$\mathrm{LA}=(\mathrm{LW} \times 0.42) \times \mathrm{N}$

Where $\mathrm{L}$ is the leaf length, $\mathrm{W}$ is leaf width and $\mathrm{N}$ is number of leaves.

From the leaf area, LAI was computed as shown:

LAI = Leaf area/Land area (Remison, 1997)

At harvest, data were collected on tuber length, tuber girth, number of tubers per plant, tuber size, tuber weight and tuber yield. Tuber weight was determined by weighing all harvested tubers within each net plot of $1 \times 1 \mathrm{~m}$ in $\mathrm{kg}$ and divided by the number of plants within the net plot. Tuber yield was estimated thus:

Tuber yield $=$ kg plant $^{-1} / 1,000$.

\section{Data analysis}

Data collected were subjected to analysis of variance using Genstat statistic software. Significantly different treatment means were separated and compared using Fisher's least significant different (LSD) at 0.05 level of probability. Pearson's correlation coefficient was used to test for correlation among the variables assessed.

\section{Results}

Physical and chemical properties of soil prior to cropping and the chemical composition of poultry manure and OPRBA

The results of the pre-cropping soil properties of the experimental site and the chemical composition of poultry manure and OPRBA are presented in Table 1 . The soil was sandy loam in both years, with strongly acidic condition in 2016 and moderately acidic in 2017. Total nitrogen, available phosphorus, exchangeable calcium and magnesium were inadequate in both years of the experiment.

Poultry manure was neutral in 2016 and slightly acidic in 2017 with high organic carbon, adequate nitrogen, moderate $\mathrm{C}: \mathrm{N}$ ratio, but low phosphorus and exchangeable cations. OPRBA was alkaline in both years. Organic carbon and total nitrogen were adequate in 2016, but low in 2017. Available phosphorus and exchangeable cations were high in both years.

\section{Growth of sweet potato}

The number of branches per plant varied significantly ( $\mathrm{p}$ $<0.05$ ) with the rates of OPRBA in 2016 and 2017 (Table 2). In 2016, number of branches per plant was similar when OPRBA was applied at rates of 4 and $8 \mathrm{t} \mathrm{ha}^{-1}$. At these rates, number of branches was significantly $(\mathrm{p}<0.05)$ higher than when OPRBA was applied at the rates of 0,2 and $8 \mathrm{tha}^{-1}$. In
2017, number of branches per plant was highest when OPRBA was applied at 6 and $8 \mathrm{tha}^{-1}$.

Plants treated with OPRBA at 0 and $2 \mathrm{t} \mathrm{ha}^{-1}$ had the shortest vines in 2016, while plants treated with OPRBA at $8 \mathrm{t} \mathrm{ha}^{-1}$ had the longest vines (Table 2). However, plants treated with $8 \mathrm{t} \mathrm{ha}^{-1}$ were not longer than plants treated with OPRBA rate of $6 \mathrm{t} \mathrm{ha}^{-1}$. In 2017 , only plants treated with OPRBA at $10 \mathrm{t} \mathrm{ha}^{-1}$ had vines significantly $(\mathrm{p}<0.05)$ longer than those of non-OPRBA treated plants.

The highest number of nodes per plant was recorded for plants fertilized with OPRBA at $4 \mathrm{t} \mathrm{ha}^{-1}$ in 2016 (Table 2). At this rate, number of nodes was not significantly ( $\mathrm{p}>$ 0.05 ) higher than when OPRBA was applied at rates of 2 and $8 \mathrm{tha}^{-1}$. In 2017, OPRBA rate of $4 \mathrm{tha}^{-1}$ produced the highest number of nodes (Table 2). In 2016, the highest number of leaves was observed in plants grown with OPRBA at 4-8 $\mathrm{tha}^{-1}$. However, in 2017, OPRBA rates of 6$10 \mathrm{t} \mathrm{ha}^{-1}$ had similar number of leaves, but significantly $(\mathrm{p}<$ 0.05 ) higher than when OPRBA was not applied.

LAI increased significantly with increased rate of OPRBA in both years (Table 3). The OPRBA rate of $8 \mathrm{t}$ $\mathrm{ha}^{-1}$ had the highest LAI in 2016. In 2017, OPRBA rates of $4-10 \mathrm{t} \mathrm{ha}^{-1}$ had similar LAI, but significantly $(\mathrm{p}<0.05)$ higher than when OPRBA was not applied. Total dry weight was significantly $(\mathrm{p}<0.05)$ highest in plots fertilized with OPRBA at $8 \mathrm{t} \mathrm{ha}^{-1}$ in 2016. In 2017, only plants fertilized with OPRBA at $4 \mathrm{t} \mathrm{ha}^{-1}$ were significantly ( $\mathrm{p}<$ 0.05 ) higher than when OPRBA was not applied.

\section{Tuber yield and yield components of sweet potato}

Tubers were the longest when OPRBA was applied at rates of 6 and $8 \mathrm{t} \mathrm{ha}^{-1}$ in 2016 (Table 4). In 2017, tubers were the longest when plants were fertilized with OPRBA at $10 \mathrm{t} \mathrm{ha}^{-1}$, but were not different from when OPRBA was applied at $8 \mathrm{t} \mathrm{ha}^{-1}$ (Table 4). OPRBA rates of 4-8 $\mathrm{t} \mathrm{ha}^{-1}$ had similar tuber girth, but significantly $(\mathrm{p}<0.05)$ thicker than when plants were fertilized with OPRBA at 0 and $2 \mathrm{t} \mathrm{ha}^{-1}$ in 2016. In 2017, plants treated with $10 \mathrm{t} \mathrm{ha}^{-1}$ of OPRBA were only significantly thicker than OPRBA was not applied. The highest number of tubers per plants was recorded for plants treated with $6 \mathrm{t} \mathrm{ha}^{-1}$ of OPRBA which were however, not significantly higher than when OPRBA was applied at 8 t ha ${ }^{-1}$ in 2016. In 2017, OPRBA had no significant effect on the number of tubers per plant. Increases in the rates of OPRBA led to an increase in tuber size in both years of the experiment. However, OPRBA applied at rates of 6 and $8 \mathrm{t}$ $\mathrm{ha}^{-1}$ resulted in similar tuber size, but significantly $(\mathrm{p}<0.05)$ longer than other rates, including control, in both years.

Table 2. Number of branches, vine length, number of nodes and number of leaves of sweet potato as influenced by oil palm refuse bunch ash (OPRBA) rate

\begin{tabular}{|c|c|c|c|c|c|c|c|c|}
\hline \multirow{2}{*}{$\frac{\text { OPRBA }}{\left(\mathrm{tha}^{-1}\right)}$} & \multicolumn{2}{|c|}{ Number of branches } & \multicolumn{2}{|c|}{ Vine length $(\mathrm{cm})$} & \multicolumn{2}{|c|}{ Number of nodes } & \multicolumn{2}{|c|}{ Number of leaves } \\
\hline & 2016 & 2017 & 2016 & 2017 & 2016 & 2017 & 2016 & 2017 \\
\hline 0 & 2.43 & 2.25 & 70.20 & 110.20 & 21.00 & 15.10 & 24.95 & 34.60 \\
\hline 2 & 2.67 & & 75.40 & & 25.50 & & 33.67 & \\
\hline 4 & 3.50 & 2.67 & 94.90 & 123.60 & 29.17 & 26.90 & 52.33 & 48.40 \\
\hline 6 & 3.00 & 2.92 & 109.70 & 127.50 & 24.50 & 21.70 & 52.00 & 44.60 \\
\hline 8 & 3.50 & 3.42 & 113.80 & 130.10 & 28.17 & 20.80 & 51.00 & 47.30 \\
\hline 10 & & 3.08 & & 145.20 & & 23.40 & & 49.50 \\
\hline $\operatorname{LSD}_{(0.05)}$ & 0.446 & 0.383 & 11.710 & 21.030 & 3.893 & 3.320 & 4.402 & 5.660 \\
\hline
\end{tabular}


Table 3. Leaf area index and total dry weight of leaves of sweet potato as influenced by oil palm refuse bunch ash (OPRBA)

\begin{tabular}{ccccc}
\hline OPRBA & \multicolumn{2}{c}{ Leaf area index } & \multicolumn{2}{c}{ Total dry weight $\left(\mathrm{g} \mathrm{m}^{-2}\right)$} \\
\hline$\left(\mathrm{t} \mathrm{ha}^{-1}\right)$ & 2016 & 2017 & 2016 & 2017 \\
\hline 0 & 2.17 & 4.75 & 231.70 & 160.20 \\
2 & 4.23 & & 259.10 & 290.20 \\
4 & 6.43 & 6.26 & 348.20 & 235.50 \\
6 & 8.43 & 5.97 & 392.30 & 210.00 \\
8 & 9.90 & 6.13 & 638.40 & 187.00 \\
10 & & 6.52 & & 72.070 \\
\hline
\end{tabular}

Table 4. Sweet potato tuber yield and its components as influenced by oil palm refuse bunch ash (OPRBA)

\begin{tabular}{cccccccccccccc}
\hline OPRBA & \multicolumn{2}{l}{ Tuber length $(\mathrm{cm})$} & \multicolumn{2}{c}{ Tuber girth $(\mathrm{cm})$} & \multicolumn{2}{c}{ No. of tubers plant ${ }^{-1}$} & \multicolumn{2}{c}{ Tuber size $(\mathrm{kg})$} & \multicolumn{2}{c}{ Tuber weight $(\mathrm{kg})$} & \multicolumn{2}{c}{ Tuber yield $\left(\mathrm{t} \mathrm{ha}{ }^{-1}\right)$} \\
\hline$\left(\mathrm{t} \mathrm{ha}^{-1}\right)$ & 2016 & 2017 & 2016 & 2017 & 2016 & 2017 & 2016 & 2017 & 2016 & 2017 & 2016 & 2017 \\
\hline 0 & 4.07 & 11.67 & 3.18 & 19.00 & 1.33 & 2.00 & 0.37 & 0.14 & 0.35 & 0.28 & 12.83 & 10.40 \\
2 & 4.41 & & 4.05 & & 1.67 & & 0.38 & & 0.58 & & 21.11 \\
4 & 4.77 & 12.17 & 4.73 & 22.67 & 1.60 & 2.33 & 0.49 & 0.23 & 0.89 & 0.51 & 32.78 & 18.70 \\
6 & 6.57 & 13.22 & 5.93 & 21.78 & 2.67 & 2.33 & 0.77 & 0.32 & 1.36 & 0.79 & 50.22 & 29.10 \\
8 & 6.07 & 14.28 & 4.72 & 23.83 & 2.00 & 2.33 & 0.74 & 0.31 & 1.21 & 0.81 & 41.22 & 30.00 \\
10 & & 15.33 & & 28.44 & & 2.33 & & 0.28 & & 0.87 & & 32.00 \\
$\operatorname{LSD}_{(0.05)}$ & 0.727 & 1.223 & 1.364 & 5.400 & 0.688 & ns & 0.075 & 0.173 & 0.111 & 0.394 & 4.410 & 14.540 \\
\hline
\end{tabular}

ns - Not significant at 0.05 level of probability

Table 5. Correlation coefficients among growth and yield variables of sweet potato

\begin{tabular}{|c|c|c|c|c|c|c|c|c|c|c|c|c|}
\hline Trait & $\begin{array}{c}\text { Plant } \\
\text { dry } \\
\text { weight }\end{array}$ & LAI & $\begin{array}{c}\text { No. of } \\
\text { branches }\end{array}$ & $\begin{array}{l}\text { No. of } \\
\text { leaves }\end{array}$ & $\begin{array}{l}\text { No. of } \\
\text { nodes }\end{array}$ & $\begin{array}{l}\text { No. of } \\
\text { tubers }\end{array}$ & $\begin{array}{l}\text { Tuber } \\
\text { girth }\end{array}$ & $\begin{array}{l}\text { Tuber } \\
\text { length }\end{array}$ & $\begin{array}{c}\text { Tuber } \\
\text { size }\end{array}$ & $\begin{array}{l}\text { Tuber } \\
\text { weight }\end{array}$ & $\begin{array}{l}\text { Tuber } \\
\text { yield }\end{array}$ & $\begin{array}{l}\text { Vine } \\
\text { length }\end{array}$ \\
\hline Plant dry weight & 1.000 & & & & & & & & & & & \\
\hline Leaf area index & $0.896^{*}$ & 1.000 & & & & & & & & & & \\
\hline No. of branches & $0.733^{*}$ & $0.736^{*}$ & 1.000 & & & & & & & & & \\
\hline No. of leaves & $0.688^{*}$ & $0.903^{*}$ & $0.785^{*}$ & 1.000 & & & & & & & & \\
\hline No. of nodes & $0.526^{*}$ & $0.621^{*}$ & $0.629^{*}$ & $0.734^{*}$ & 1.000 & & & & & & & \\
\hline No. of tubers & 0.317 & $0.437^{*}$ & 0.010 & 0.247 & 0.189 & 1.000 & & & & & & \\
\hline Tuber girth & 0.362 & $0.626^{*}$ & 0.395 & $0.663^{*}$ & 0.288 & $0.585^{*}$ & 1.000 & & & & & \\
\hline Tuber length & $0.659^{*}$ & $0.805^{*}$ & 0.430 & $0.691^{*}$ & 0.252 & $0.605^{*}$ & $0.635^{*}$ & 1.000 & & & & \\
\hline Tuber size & $0.806^{*}$ & $0.916^{*}$ & $0.589^{*}$ & $0.772^{*}$ & 0.310 & $0.586^{*}$ & $0.587^{*}$ & $0.866^{*}$ & 1.000 & & & \\
\hline Tuber weight & $0.755^{*}$ & $0.942^{*}$ & $0.684^{*}$ & $0.881^{*}$ & $0.448^{*}$ & $0.553^{*}$ & $0.738^{*}$ & $0.865^{*}$ & $0.953^{*}$ & 1.000 & & \\
\hline Tuber yield & $0.748^{*}$ & $0.938^{*}$ & $0.679^{*}$ & $0.879^{*}$ & $0.440^{*}$ & $0.561^{*}$ & $0.751^{*}$ & $0.864^{*}$ & $0.952^{*}$ & $1.000^{*}$ & 1.000 & \\
\hline Vine length & $0.841^{*}$ & $0.931^{*}$ & $0.767^{*}$ & $0.846^{*}$ & $0.492^{*}$ & $0.456^{*}$ & $0.623^{*}$ & $0.751^{*}$ & $0.914^{*}$ & $0.940^{*}$ & $0.518^{*}$ & 1.000 \\
\hline
\end{tabular}

Tuber weight was highest when OPRBA was applied at $6 \mathrm{t} \mathrm{ha}^{-1}$ in 2016. In 2017, there were no significant differences in tuber weight when OPRBA was applied at rates of 6-10 $t \mathrm{ha}^{-1}$. At these rates tuber weight was higher than when OPRBA was applied at 0 and $4 \mathrm{t} \mathrm{ha}^{-1}$. The highest tuber yield was obtained when OPRBA was applied at rate of $6 \mathrm{t} \mathrm{ha}^{-1}$ in 2016. However, in 2017, tuber yield was similar when OPRBA was applied at rates of 6-10 $\mathrm{tha}^{-1}$, but was significantly higher than when OPRBA was applied at 0 and $4 \mathrm{tha}^{-1}$.

Correlation coefficients among growth and yield variables in sweet of sweet potato

Correlation matrix of variables of sweet potato as influenced by different rates of OPRBA is presented in
Table 5. It was observed that total dry weight had significant $(\mathrm{p}<0.05)$ and positive relationship with the vine length, tuber yield, tuber weight per plant, tuber size, tuber length, number of nodes, number of leaves, number of branches and leaf area index. However, total dry weight relationship with tuber girth and number of tubers per plant were not significant $(\mathrm{p}>0.05)$. LAI showed significant $(\mathrm{p}<0.05)$ and positive correlation with all growth and yield variables.

\section{Discussion}

The soil of the studied site was acidic and low in nutrients, indicating a low fertile soil. This finding is in agreement with Awodun et al. (2007) who reported that most soils in the humid tropical forest regions are acidic due 
412

to high rainfall intensity and associated leaching of nutrients. The low soil $\mathrm{pH}$ of the studied site could also be related to the very high proportion of sand particles in relation to other particles in the area, which might have increased the level of leaching of the basic nutrient from the soil, thereby increasing the exchangeable acidity.

To attain the potential tuber yield, the plants need adequate nutrients since the crop is a heavy feeder (Fageria et al., 2011). This necessitated the inclusion of fertilizer input in the study. Ali et al. (2009) reported that the application of fertilizer is one of the most important inputs for increasing the productivity of crops. Bationo et al. (2012) reported that larger yield can be achieved for a given quantity of fertilizer applied, or less fertilizer is required to achieve a particular yield target. In the present study, the application of poultry manure enriched the soil with organic carbon, total nitrogen and other nutrients. However, the manure was low in available phosphorus and exchangeable cations.

The addition of OPRBA improved the soil $\mathrm{pH}$ and enriched the soil with available phosphorus and exchangeable cations. The result is evidenced from the hereby analysis of OPRBA which showed a number of plant nutrients that would be made available to the plant through its application. The increase in the number of branches, nodes and leaves, vine length, LAI and total dry weight of the treated plants, indicate that the poultry manure enriched with OPRBA was beneficial to the plants and thus top the crop. Such observation is in line with the finding of Ezekiel et al. (2003) who reported the application of OPRBA lead to corresponding increase in number of leaves per plant, plant height and stem girth of cassava. Jonna (2017) reported significant increase in plant biomass as a result of wood ash application.

OPRBA treated plants exhibited longer vines, which is a precursor to higher number of leaves and LAI as these parameters are positively correlated. As a consequence, high amount of radiation is intercepted, contributing to an increase in tuber yield in relation to plants that did not receive OPRBA. This finding is in agreement with LawOgbomo and Remison (2007) who reported that tuber yield in yam is dependent on the amount, rate and duration of assimilates translocated to it.

The increase in sweet potato tuber yield was probably due to the release of nutrients from OPRBA to plants, which increased the tuber yield of the crop significantly (Ezekiel et al., 2003). Ojeniyi et al. (2009) also reported high root yield following application of OPRBA. The high potassium content of the ash which was eventually released into the soil, enhanced translocation of assimilates into storage organ. The lower yield associated with plants not fertilized with OPRBA could probably be due to poor availability of exchangeable cations for the plants to be utilized. These plants had lower number of branches, lower number of leaves and lower number of nodes, lower LAI and lower total dry weight due to low nutrient content of the soil. This led to lower tuber yields when compared with plants that received OPRBA.

\section{Conclusions}

Poultry manure enriched with OPRBA improved the growth and yield of sweet potato. Tuber yield was maximized when OPRBA was applied at a rate of $6 \mathrm{t} \mathrm{ha}^{-1}$ in both years of the experiment. Based on these current findings, farmers should enrich poultry manure with oil palm refuse bunch ash at a rate of $6 \mathrm{tha}^{-1}$ for every $15 \mathrm{tha}^{-1}$ of poultry manure to increase the productivity of sweet potato in soils of low fertility status.

\section{Conflict of Interest}

The authors declare that there are no conflicts of interest related to this article.

\section{References}

Amede T, German L, Rao C, Opondo C, Stroud A (2006). Integrated natural resource management in practice: enabling communities to improve mountain livelihoods and landscapes. In: Proceedings of the African Highland Initiative Conference, October, 2004, pp 1215.

Awodun MA, Ojeniyi SO, Adeboye A, Odedina SA (2012). Effect of oil palm bunch refuse ash on soil and plant nutrient composition on yield of maize. American-Eurasian Journal of Sustainable Agriculture 1(1):5054.

Bationo A, Fairhurst T, Giller K, Kelly V, Lunduka R, Mando A, Shamie Z (2012). Handbook for integrated soil fertility management. Technical Centre for Agricultural and Rural Cooperation.

Ezekiel PO, Ojeniyi SO, Asawalaam DO, Awo AO (2003). Root growth, dry root yield and N, P, K content of cassava as influenced by oil palm bunch ash on ultisols of southeast Nigeria. Nigerian Journal of Soil Science 19(1):6-10.

Fageria NK, Baligar VC, Jones CA (2011). Growth and mineral nutrition of field crops. $2^{\text {nd }}$ edition. MarcelDekker Inc. New York.

FAO (2008). Corporate Document Repository. The impact of HIV/AIDS on the agricultural sector. Retrieved 2015 February 28 from http://www.fao.org/docrep/005/Y4636E/y4636e05.htm.

Isherwood KF (2008). Fertilizer use and the environment. Revised Edition. International Fertilizer Inductry Association, Paris, France.

Jonna W (2006). Effects of wood ash on soil fertility and plant performance in southwestern Kenya. Master's Thesis in Soil Science. Faculty of Natural Resources and Agricultural Sciences, Swedish University of Agricultural Sciences, pp 54.

Karam F, Rouphad Y, Lahoud R, Breidi J, Coll G (2009). Influence of genotypes and potassium application rates on yield and potassium use efficiency of potato. Journal of Agronomy 8(1):27-32.

Law-Ogbomo KE, Remison SU (2007). The response of Dioscorea rotundata to NPK fertilizer application in Edo State, Nigeria. Research Journal of Agriculture and Biological Science 3(6):917-923.

Mylavarapu RS, Kennelley DE (2002). UF/IFAS extension soil testing laboratory (ESTL): Analytical procedures and training manual. Institute of Food and Agricultural Sciences, University of Florida, Gainesville, USApp 28 . 
Nyakafewa EZ, Reddy KC, Sistani KR (2001). Tillage, cover cropping and poultry litter effects on soil chemical properties. Soil Tillage Resources 58(1-2):69-79.

Ogoke IJ, Egesi CN, Obiefuna JC (2003). A review of some non-destructive linear measurement procedures for leaf area determination in crops. International Journal of Agriculture and Rural Development 4(1):74 80.
Ojeniyi SO, Ezekiel PO, Asawalam DO, Awo AO, Odedina SA, Odedina JN (2009). Root growth and NPK status of cassava as influenced by oil palmbunch ash. African Journal of Biotechnology 8(18):4407-4412.

Remison SU (1997). Basic principles of crop physiology. Sadoh Press, Benin City, Nigeria. 